\title{
Cities to the rescue? Assessing the performance of transnational municipal networks in global climate governance
}

\author{
Jennifer S. Bansard ${ }^{1} \cdot$ Philipp H. Pattberg $^{2} \cdot$ Oscar Widerberg $^{2}$
}

Accepted: 15 March 2016/Published online: 1 April 2016

(C) The Author(s) 2016. This article is published with open access at Springerlink.com

\begin{abstract}
Despite the proliferation and promise of subnational climate initiatives, the institutional architecture of transnational municipal networks (TMNs) is not well understood. With a view to close this research gap, the article empirically assesses the assumption that TMNs are a viable substitute for ambitious international action under the United Nations Framework Convention on Climate Change (UNFCCC). It addresses the aggregate phenomenon in terms of geographical distribution, central players, mitigation ambition and monitoring provisions. Examining thirteen networks, it finds that membership in TMNs is skewed toward Europe and North America while countries from the Global South are underrepresented; that only a minority of networks commit to quantified emission reductions and that these are not more ambitious than Parties to the UNFCCC; and finally that the monitoring provisions are fairly limited. In sum, the article shows that transnational municipal networks are not (yet) the representative, ambitious and transparent player they are thought to be.
\end{abstract}

Keywords Climate change $\cdot$ Cities and regions $\cdot$ Urban politics $\cdot$ Transnational networks

Philipp H. Pattberg

philipp.pattberg@vu.nl

Jennifer S. Bansard

Jennifer.bansard@gmail.com

Oscar Widerberg

oscar.widerberg@vu.nl

1 DFG Research Training Group 1744/1 WIPCAD, Faculty of Economics and Social Sciences, University of Potsdam, Sigmaringerstr. 34, 10713 Berlin, Germany

2 Environmental Policy Analysis Department, Institute for Environmental Studies, VU University Amsterdam, De Boelelaan 1105, 1081 HV Amsterdam, Netherlands 


\section{Introduction}

Municipal and subnational climate action is a well-recognized phenomenon in global environmental governance. Cities and regions have become significant actors (Lee 2013, 108) as well as key sites of climate change governance (Castan Broto and Bulkeley 2013, 92). The idea that that cities, not states, are best equipped to deal with complex problems such as climate change has become a popular leitmotiv among academics, media and policy-makers (Kousky and Schneider 2003). Barber (2013, 5), for example, argues that local actions and global cooperation among cities could bring about a "miracle of civic "glocality" promising pragmatism instead of politics, innovation rather than ideology and solutions in place of sovereignty' and therefore might circumvent the cumbersome negotiations under the United Nation Framework Convention on Climate Change (UNFCCC). The embodiment of this civic glocality can be observed in the many transnational municipal and regional networks (TMN) created to connect cities and regions in their fight against climate change, with the C40 Cities Climate Leadership Group, the Covenant of Mayors (CoM) and the Cities for Climate Protection program (CCP) being the best known examples. Consequently, many observers expect an increasing role for TMNs in the struggle to limit global warming to $2{ }^{\circ} \mathrm{C}$ and below (Rosenzweig et al. 2010; Blok et al. 2012). However, while the phenomenon of subnational climate governance has received broad attention among academics, few studies have to date scrutinized the overall institutional architecture of urban climate governance as an interconnected and aggregate governance intervention. In fact, instead of focusing on how the overall system of TMNs is related to the UNFCCC and national mitigation pledges (for example by their ambition levels) and interacts with each other (for example through a city's membership in more than one network), research has predominantly produced exploratory single case studies or focused on explaining network membership or policy effects at the municipal level.

What is missing is a rigorous assessment of the aggregate phenomenon of transnational municipal networks in climate governance. In this contribution, we critically assess the assumption that TMNs are a feasible addition to and partial substitute for ambitious international and binding mitigation actions. For this assumption to be true, we would expect TMNs to (a) include members situated in regions with high emissions or high emission growth rates; (b) avoid duplication of work and double-counting; (c) set ambitious and unambiguous mitigation targets that go beyond what national governments have agreed to in the UNFCCC context; and (d) have appropriate monitoring mechanisms in place to report and verify commitments. Our empirical analysis suggests that the aggregate system of TMNs falls short of being an effective substitute for ambitious international climate action.

The paper proceeds as follows. Section 2 reviews existing scholarly work to date, highlighting relevant conceptualizations and definitions as well as key research findings and core assumptions. On this basis, we identify existing research gaps and propose a way forward along four guiding questions: What is the geographical distribution of cities in transnational municipal networks? Who are the central players and what overlaps exist between them? What is the current ambition level of city commitments? What monitoring and reporting mechanisms are in place to guarantee a minimum level of transparency? Section 3 presents our findings related to the geographical distribution of cities in transnational municipal networks, Sect. 4 engages with the question of overlaps and double-counting among TMNs, Sect. 5 analyzes the mitigation commitments of TMNs, and Sect. 6 scrutinizes monitoring and reporting mechanisms, before we conclude with some next steps for research on urban climate governance. 


\section{State of the art}

Subnational climate governance and the related networks among municipalities and regions are by no means a new phenomenon. At the 1992 United Nations Conference on Environment and Development (UNCED), local authorities were identified as important stakeholders with a direct link to the public, and the resulting local agenda 21 process was one of the most tangible outcomes of UNCED (1992). By 1993, the international alliance Local Governments for Sustainability (ICLEI) initiated the Cities for Climate Protection program (CCP), which quickly grew to involve hundreds of cities (Betsill and Bulkeley 2004). Local authorities' involvement in climate governance was also triggered by the first Conference of the Parties (COP) to the UNFCCC, where local government and municipal authorities were recognized as a constituency (UNFCCC 2010). Over the past decades, municipalities have been increasingly vocal in demanding recognition and support for local climate action, especially since the launch of the Local Government Climate Roadmap at COP 13 in 2007 (for a concise overview of the history of urban climate governance, see Bulkeley et al. 2012a, b, 546-548).

Cities are both part of the problem and the solution to climate change (Kamal-Chaoui and Roberts 2009). By some accounts, cities account for around $70 \%$ of global greenhouse gas (GHG) emissions, use $80 \%$ of global energy supply and consume $75 \%$ of all natural resources (UN-HABITAT 2011; UNEP 2015). Cities are considered to be laboratories of social change (Hoornweg et al. 2011) and centers of innovation for their counties and the global economy (De Sherbinin et al. 2007). Bulkeley and Castan Broto (2012) recall utopian ideals such as the garden city and highlight the experimental quality of cities. They see experimental projects as critical in creating niches which can ultimately challenge regime dominance (Bulkeley and Castan Broto 2012). This diversity and the practical nature of local projects make them 'bound to bring forward genuinely new ideas and solutions that in the end can have an impact on a larger scale' (Gustavsson et al. 2009, 21). Most scholars seem to agree that considerable work to address climate change is already being done at the subnational level and that the active integration, reinforcement and facilitation of urban climate governance are an essential issue in the development of the future climate change governance architecture (Bodansky and Diringer 2014; Schroeder and Lovell 2009). This has led Ostrom (2009) to note that 'global solutions negotiated at a global level, if not backed up by a variety of efforts at national, regional, and local levels $[\ldots]$ are not guaranteed to work well' (p. 4).

\subsection{Definitions and conceptualizations}

To refer to on the one hand municipalities and subnational regions as actors and prime sites of climate governance, and to networks of those actors on the other hand, we suggest subnational climate governance as an umbrella term, alternatives being 'urban politics of climate change' (Bulkeley and Betsill 2013) or 'urban climate governance' (e.g., Bulkeley 2010a, b). With reference to multiple interactions among individual municipalities and subnational regions, the term 'transnational municipal network' (TMN), denoting city networks of various sizes and at various levels (national, regional, global), is widely accepted among scholars (Betsill and Bulkeley 2006; Toly 2008; Kern and Bulkeley 2009; Giest and Howlett 2013). Kern and Bulkeley (2009, 309-310) suggest three defining criteria for TMNs: First, members are free to leave the network at any time; second, networks are non-hierarchical; and third, network decisions are directly implemented by the members. 


\subsection{Research foci and key findings}

Research on subnational climate governance ${ }^{1}$ has generally speaking fallen into three distinct categories: first, studies that focus on municipalities or subnational regions as the unit of analysis (Gustavsson et al. 2009; Bulkeley and Schroeder 2011; Bulkeley and Castan Broto 2012; Castan Broto and Bulkeley 2013; Bulkeley and Betsill 2013), often within the context of a specific polity (e.g., Granberg and Elander 2007 on Sweden; Schreurs 2008 on the US, Germany and Japan; Collier and Löfstedt 1997 on the UK and Sweden). Second, studies that focus on transnational municipal networks as the unit of analysis (Betsill and Bulkeley 2004; Bulkeley 2005; Betsill and Bulkeley 2006; Toly 2008; Kern and Bulkeley 2009; Lee and van de Meene 2012; Giest and Howlett 2013). The majority of studies that focus on TMNs as governance instruments (with the notable exception of Bulkeley et al. 2012a, b) however use a (sometimes comparative) case study approach. The Cities for Climate Protection (CCP) program has been by far the most popular case (e.g., Betsill and Bulkeley 2004, 2006; Toly 2008), followed by the Cities Climate Leadership Group, C40 (Lee and van de Meene 2012; Acuto 2013; Bouteligier 2013). Case studies are also available for less well-known networks such as the International Solar Cities Initiative, ISCI (Toly 2008), the Climate Alliance and the Energy Cities network (Kern and Bulkeley 2009).

A third group of studies can be identified that links municipal and subnational climate policy with transnational municipal networks as a distinct form of governance. Exploring the link between city-specific characteristics (such as being hubs of international economic and policy interactions) and membership in TMNs, Lee (2013) finds that globalization is a driving factor for city participation in transnational networks. A reverse argument is considered by Krause (2012) and Lee and Koski (2014) when the impact of network membership on actual climate policy performance is scrutinized. Both studies confirm a moderately positive effect of network membership on levels of policy implementation for the C40 and CCP cities, but not for the US Conference of Mayors' Climate Protection Agreement, thus pointing to existing functional differences among TMNs.

In addition to broader conceptual questions about the significance of subnational climate governance, scholars have asked a variety of questions: What determines policy effectiveness and ambition levels of municipal climate actions (exploring both city internal and external factors)? What determines membership in transnational municipal networks? What concrete urban policies and instruments are used to address climate change (in the words of Castan Broto and Bulkeley 2013: urban climate change experiments)? How are global power relations reflected in TMNs (is there a North-South divide in subnational climate governance)? Much of the literature also analyzes concrete examples of subnational mitigation policies (Comodi et al. 2012; Corfee-Morlot et al. 2009; Gustavsson et al. 2009); these relate to various sectors and actions, including energy (e.g., combined heat and power generation); transport (e.g., alternative transportation infrastructure); land-use planning (e.g., reduction in commuting distances, traffic management); buildings (e.g., insulation and lighting standards); waste management (e.g., methane recovery); and citizen outreach (e.g., education and training). To study these questions, a broad range of theoretical approaches, from actor-network theory to multi-level governance and neo-Gramscian governmentality, have been applied (Acuto 2013; Bulkeley and Schroeder 2011).

\footnotetext{
1 Predominantly, studies focus on climate change mitigation; studies that address climate change adaptation are still rare (with the exception of Juhola and Westerhoff 2011; Fünfgeld 2015).
} 


\subsection{The research gap}

While research has produced valuable insights into causes and consequences of urban climate governance and transnational municipal networks, we are currently lacking a systematic assessment of the broader institutional architecture of networked urban climate governance. Such an assessment is required for a number of reasons: First, the predominant focus on one or two popular cases of city networks has so far stood in the way of assessing the overall geographical spread of cities participating in governance networks. Second, overlap between networks in terms of city membership might lead to double-counting of commitments or forum shopping behavior (choosing the appropriate venue for furthering individual interests); therefore, only an aggregate view can meaningfully assess the broader impacts of TMNs. Third, there is a tendency to perceive TMNs as a unified and coherent phenomenon. However, only an aggregate analysis of the entire governance field can reveal the coherence or incoherence of municipal climate actions in terms of ambitions levels, base years, measurement metrics and other variable factors. Fourth, the networks are seen as less subject to political bargaining and more focused on the delivery of results than the UNFCCC; yet, the reporting mechanisms that could prove this assumption have not been examined. In other words, is the aggregate phenomenon of transnational municipal networks a viable alternative to international top-down climate governance?

Consequently, in our empirical analysis we assess a set of thirteen TMNs along four guiding questions: First, is urban climate governance a global phenomenon or are some regions better represented than others? Second, to what degree does membership in municipal and subnational climate networks overlap and how does connectedness vary across networks? Third, do TMNs commit to ambitious emission reductions and how do these compare to national commitments under the UNFCCC? And fourth, how is their progress monitored and verified in order to guarantee transparency? In sum, we analyze the broader governance architecture of TMNs in order to assess their potential contribution to climate change mitigation.

The thirteen TMNs have been selected following a literature review and complemented with a Web search using English, French, German and Spanish keywords on the Google search engine. ${ }^{2}$ Four selection criteria were used. First, we focus on climate mitigation action and exclude networks working on adaptation or general sustainable development issues (e.g., the Asian Cities Climate Change Resilience Network, MayorsAdapt or ICLEI-Local Governments for Sustainability). Second, the network should be transnational and include subnational authorities in at least two states, thus excluding singlecountry networks (e.g., the Regional Greenhouse Gas Initiative in the USA). Third, the networks should have a functioning and recently updated Web site. Fourth, meta-networks, i.e., those whose members are networks themselves (e.g., the United Cities and Local Governments), were also excluded. Table 1 gives an overview of the TMNs in our sample.

\section{Geographical distribution in transnational municipal networks}

The membership to the UNFCCC is nearly universal and therefore represents (at least in theory) virtually all GHG emissions. To what extent can TMNs match this level of representation? Since cities are believed to account for approximately $70 \%$ of global emissions (UN-Habitat 2011), they have the potential to change the course of a country's

\footnotetext{
${ }^{2}$ Key words are on file with corresponding author.
} 
Table 1 Overview TMNs

\begin{tabular}{|c|c|c|c|c|c|c|}
\hline & Name & Abbreviation & Members & Year & Type & Geography \\
\hline 1 & $\begin{array}{l}\text { Climate Alliance of European Cities } \\
\text { with Indigenous Rainforest Peoples }\end{array}$ & $\begin{array}{l}\text { Climate } \\
\text { Alliance }\end{array}$ & 1717 & 1990 & Cities & $\begin{array}{l}\text { Europe/Latin } \\
\text { America }\end{array}$ \\
\hline 2 & Covenant of Mayors & $\mathrm{CoM}$ & 5717 & 2008 & Cities & Europe \\
\hline 3 & EUROCITIES & EUROCITIES & 45 & 1986 & Cities & Europe \\
\hline 4 & $\begin{array}{l}\text { C40 Cities Climate Leadership } \\
\text { Group }\end{array}$ & $\mathrm{C} 40$ & 75 & 2005 & Cities & Global \\
\hline 5 & EnergyCities & EnergyCities & 184 & 1990 & Cities & Europe \\
\hline 6 & Union of the Baltic Cities & UBC & 93 & 1991 & Cities & Baltic \\
\hline 7 & Regions of Climate Action & $\mathrm{R} 20$ & 92 & 2010 & Regions & Global \\
\hline 8 & $\begin{array}{l}\text { New England Governors and Eastern } \\
\text { Canadian Premiers' Annual } \\
\text { Conference }\end{array}$ & NEG/ECP & 11 & 1973 & Regions & North America \\
\hline 9 & $\begin{array}{l}\text { World Mayors Council on Climate } \\
\text { Change }\end{array}$ & WMCCC & 88 & 2005 & Cities & Global \\
\hline 10 & $\begin{array}{l}\text { The Climate Group (States and } \\
\text { Regions) }\end{array}$ & TCG-SR & 27 & 2005 & Regions & Global \\
\hline 11 & North America 2050 & NA2050 & 20 & 2009 & Regions & North America \\
\hline 12 & International Solar Cities Initiative & ISCI & 5 & 2003 & Cities & Global \\
\hline 13 & Western Climate Initiative & WCI & 5 & 2007 & Regions & North America \\
\hline
\end{tabular}

emission pattern. For TMNs to have a credible possibility to change current emission trajectories toward decarbonization, however, they should represent a substantive portion of both current and future emissions. Previous research has shown that transnational governance initiatives are generally a phenomenon concentrated in the Global North (Bulkeley et al. 2012a, b). The EU and the USA are in effect both major emitters with roughly 13 and $20 \%$ of global $\mathrm{CO}_{2}$ emissions in 2013, respectively; however, due to rapidly growing economies such as China, Brazil and India, their share in total emissions is shrinking (WRI 2014), making it increasingly important to engage actors in the Global South.

To understand the geographical distribution of subnational governments in our sample of TMNs, we plotted all 7677 cities and regions on a world map. The result is shown in Fig. 1.

The map shows a high concentration of cities and regions in the Global North, in particular Europe and the USA. The cluttered pattern in Europe is partly due to the relatively large number of TMNs with a European focus and the presence of two very large networks including the Covenant of Mayors and the Climate Alliance, with more than 1000 member cities each. In Latin America, Oceania and Asia, a scattered pattern of city participation emerges mainly comprising capitals and large cities. In Africa on the other hand, except South Africa, most countries have very few to no cities engaging in TMNs. Overall, the skewed geographical distribution of cities and regions toward Europe and North America confirms the previously noted bias toward the Global North.

While Europe is overrepresented in terms of cities part of TMNs, it is not the world's largest emitter of GHGs accounting for $13 \%$ of global emissions in 2013 (JRC 2014). For global GHG emissions to be better covered by TMNs, one would expect to find more members in countries with large domestic emission such as Australia and Russia and 


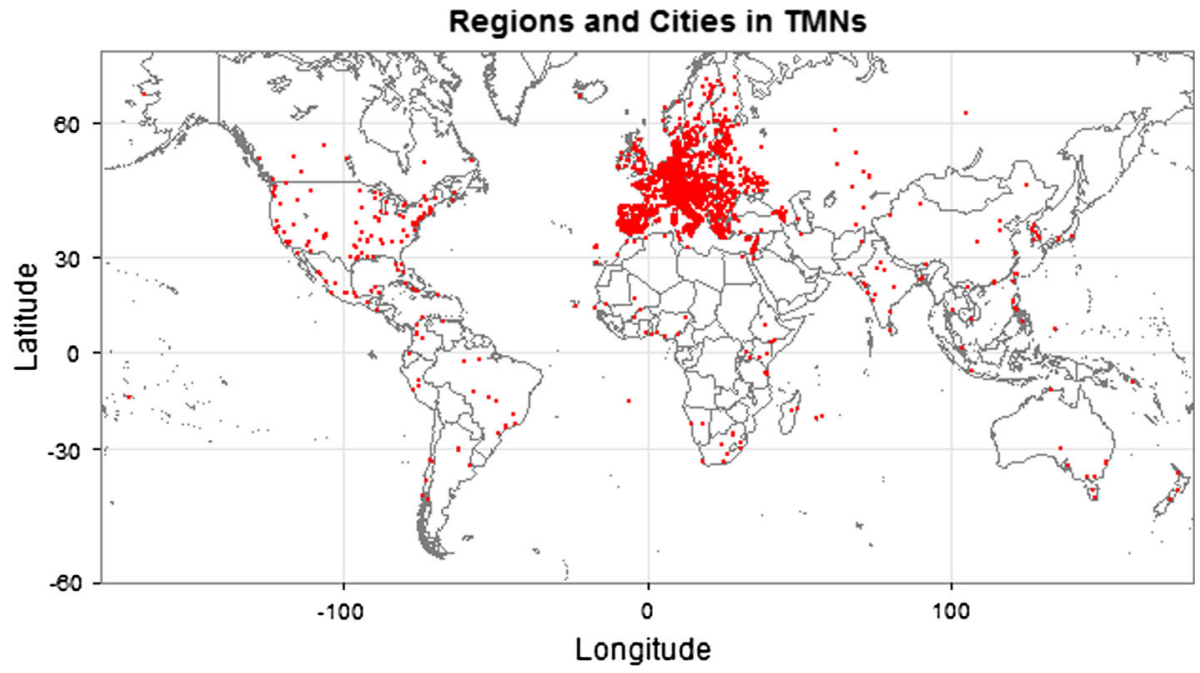

Fig. 1 Regions and Cities in TMNs

particularly in countries with steadily increasing emission patterns, including developing countries with fast-growing economies such as China, India and Brazil (Olivier et al. 2014).

The data are difficult to interpret, however, for three reasons. First, it matters which cities are represented. The C40, for example, represents 75 cities which in our sample is a fairly small TMN in terms of number of members. However, these cities represent more than 500 million people and $25 \%$ of the global GDP. The total emissions of the 33 cities that disclose information on the $\mathrm{C} 40$ homepage ${ }^{3}$ amount to $0.6 \mathrm{Gt}$ of $\mathrm{CO}_{2}$ equivalent annually, which is equal to roughly two times the annual emissions of Poland. ${ }^{4}$ Small TMNs can thus account for a sizeable portion of global GHG emissions if they include the largest polluters.

Second, some TMNs are not represented in our sample. For instance, the large city network ICLEI-Local Governments for Sustainability-has been excluded from the sample due to its general focus on sustainable development. It however contains highly active local chapters in countries, such as Canada, which are not well represented in our mapping exercise. National networks are also emerging in fast-growing economies such as China, where a China Regional Low Carbon Alliance was announced in 2014 comprising nine subnational jurisdictions across China (The Climate Group 2014).

Third, cities that take climate action but are not part of TMNs are not represented in our sample. While in our analysis we solely focused on TMNs as an alternative form of climate governance, they should not be equated with subnational mitigation action as such. Evidently, cities and regions can take ambitious mitigation action without being part of a TMN.

\footnotetext{
${ }^{3}$ http://www.c40.org/research/open_data/1.

4 Total anthropogenic CO2 emissions excluding emissions/removals from land use, land-use change and forestry in 2012, reported by Poland to the UNFCCC ( $0.3 \mathrm{Gt}$ of $\mathrm{CO}_{2}$ equivalent annually), see FCCC/SBI/ $2014 / 20$.
} 


\section{Overlaps and central nodes in transnational municipal network}

Under the current UNFCCC regime, countries are responsible for all economic activity leading to GHG emissions. National borders thus provide a clearly demarcated framework for attributing rights and obligations with regard to emissions and decarbonization. Switching focus to subnational administrative entities blurs these borders and makes it more difficult to calculate who is doing what and where. For instance, Paris is situated in Île-de-France, also known as 'Paris Region,' where both have committed to climate action and have joined different TMNs. What happens if there are substantive emission reductions made in Paris, would that be attributed to the city, the region and to which TMN? There is hence a risk of overlap and double-counting when assessing the potential impacts of the different TMNs (see also Widerberg and Pattberg 2015).

Estimating the size and nature of the overlap is a matter of making the right assumptions. UNEP (2015), for instance, uses a set of 'back-of-the-envelope' estimations to calculate the overlap between potential emissions reductions in cities and regions and companies, simply stating that the overlap is $0.11 \mathrm{GtCO}_{2} \mathrm{e}$, totaling a total emission reduction potential of the $1.73 \mathrm{GtCO}_{2} \mathrm{e}$ (UNEP 2015). While this approach might be pragmatic, it could be improved by more detailed analysis of actors that participate in several networks.

Our approach to the issue of overlaps in commitments between cities and regions is to apply network analysis, using the sample of thirteen networks and 7677 unique cities and regions as nodes connected by membership creating 8013 edges. A $k$-core analysis-which subsets of nodes that are connected to $k$ or more other nodes - unveils that only a relatively small group of 288 nodes are part of more than one network $(k=2)$. An even smaller subset of 45 nodes connects all thirteen TMNs with one another. These 'super-connectors' include mainly European cities such as Barcelona and Malmö (5 edges), but also North American states such as California and Connecticut. The relationships between the superconnectors are visualized in Fig. 2 and show how two clusters of cities and regions are formed. The city cluster includes CoM, UBC, C40, Eurocities, Energycities, WMCCC, Climatealliance, ISCI and C40. The region cluster includes NEGECP, R20, TCG, NA2050 and WCI.

The visualization reveals those cities and regions that are part of the same subnetwork of networks and have a higher risk of being double-counted. The network analysis also indicates how some actors are acting as gatekeepers between the networks. The central role of the city of Vienna and the region of Île-de-France as gatekeepers between the clusters is clearly visible. However, identifying the central actors that connect the two clusters can also be done computationally by measuring the degree of betweenness, i.e., number of shortest paths from all nodes to one another passing through that node. The practical meaning of betweenness centrality for a city could be understood in a number of ways. For instance, cities or regions that connect TMNs across geographical regions such as Europe and the USA could be considered bridges between different policy settings and therefore to facilitate exchange of expertise, know-how and experience throughout the network. Calculating betweenness confirms Vienna and Ile de France's central positions; however, Bonn, Heidelberg, Berlin, Rostock, Oxford and Connecticut also act as local bridges in their respective clusters.

The set of central actors identified by the network analysis reflects the concentration of TMNs in Europe and North America. Among the super-connectors, not a single city or region is from a developing country. This supports the findings of the previous section that 


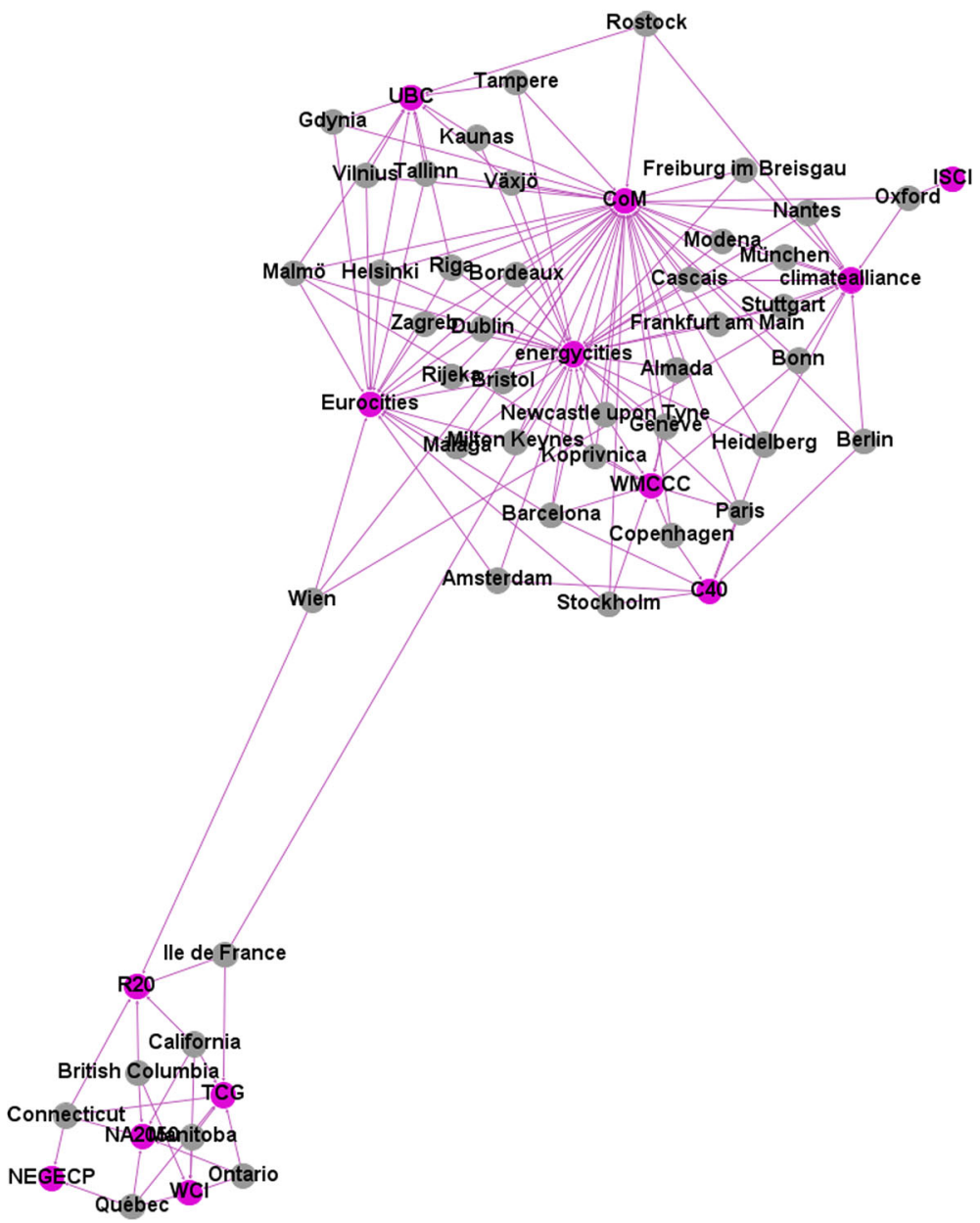

Fig. 2 Super-connectors in the TMNs

TMNs are largely a European and North American phenomenon, with few and scattered links to cities in large emitting countries such as China, India and Brazil. On this account, TMNs are not an alternative form of climate governance, but rather replicate existing policy networks mainly among the USA and Europe.

\section{Mitigation commitments}

Breaking news: \#COP21 cancelled as cities have put the world back on track - At an emergency press conference organised this morning, UN Secretary General Ban Kimoon announced the amazing news: local authorities have won the fight against climate change.[...] 'There is no need for such a conference anymore. Cities have 
done what we couldn't do at this governance level', Ban Ki-moon says. (Energy

Cities 2015)

With their April Fools' joke, Energy Cities aligns with Barber (2013) in illustrating the general perception that with more ambitious mitigation action taken at the local than at national level, TMNs are succeeding where the UNFCCC fails. Addressing this generic perception, the following section presents our assessment of the type and ambition level of the mitigation commitments found in our sample of thirteen TMNs.

A striking finding is that, with the exception of the Climate Alliance, the CoM and the WCI, agreeing on an emission reduction target, are not a prerequisite for membership in the examined TMNs. Eligibility is rather based on geographic location (e.g., UBC, NEG/ ECP), a threshold in terms of number of inhabitants or GDP (e.g., C40), qualitative commitments toward climate change mitigation (e.g., C40, Energy Cities, R20, WMCCC, TCG-SR, ISCI) or a combination of these criteria (e.g., EUROCITIES, NA2050).

Our analysis of the type of mitigation commitment is in line with this first observation: The majority of the TMNs we examined only issue qualitative commitments toward climate change mitigation. These consist of commitments to 'work toward progressive policies to address climate change' (R20 2014) or to 'demonstrating climate leadership' (NA2050 2014). Only four TMNs issue quantified emission reduction targets: $10 \%$ every 5 years for the Climate Alliance (Klimabündnis 2014), to meet and exceed the EU's $-20 \%$ by 2020 target for the CoM (2014b); $-15 \%$ by 2020 compared to 2005 for the WCI (2007); and $-10 \%$ by 2020 compared to 1990 for the NEG/ECP (2001). The remaining nine TMNs focus on soft mitigation actions, for example by exchanging best practices and providing capacity building measures. Contrary to the UNFCCC, the type of commitment of TMNs was not found to be dependent on greenhouse gas emission/development levels or another rationale. As contentious as the principle of common but differentiated responsibility and respective capabilities (CBDR-RC) might be (see e.g., Pauw et al. 2014), it clearly sets apart the UNFCCC with regard to ethical considerations and efficacy. Beyond opening up questions about a lack of political will, it shows that TMNs are currently circumventing rather than successfully dealing with one of the essential challenges for international climate governance.

A second observation is that existing quantitative targets differ with regard to their framing, both in terms of metrics (e.g., absolute and per capita targets) and timescale (varying base and target years). Differing framings make an evaluation and comparison of targets difficult as they blur the relation between reduction level and target ambition. One example illustrating how varying target framings stand in the way of transparency and a critical assessment of mitigation commitments is the C40. Although the network does not commit to quantitative emission reductions itself, and only $46 \%$ of its members appear to have voluntarily set such a target, the network prominently displays these on its Web site. Figure 3 provides a detailed overview of timescales and reduction levels of the different member targets observable in the $\mathrm{C} 40(2014 \mathrm{a}, \mathrm{b})$. The lengths of the respective lines correspond to the timescale (base year on the left; target year on the right) and the shading to the reduction level (darker shading represents higher reduction levels). The figure illustrates the use of nine different base years and seven different target years, with 1990 and 2020 each being used in close to $44 \%$ of the members' targets. Furthermore, targeted reduction levels range from 7 to $100 \%$ on various timescales.

While the absence of specific data on individual emission paths inhibits a comparison of the ambition levels of C40 member targets, we were able to do so for the four TMNs that do set quantified targets at network level. With 1990-2020 already being used by two 


Addis Ababa
Johannesburg
Tokyo
Yokohama
Seoul
Paris
Berlin
Rome
Venice
Amsterdam
Warsaw
Moscow
Madrid
Stockholm
London
Buenos Aires
Rio de Janeiro
Sao Paulo
Bogota
Toronto
Vancouver
Boston
Chicago
Los Angeles
Philadelphia
Portland
Seattle
Melbourne
Sydney

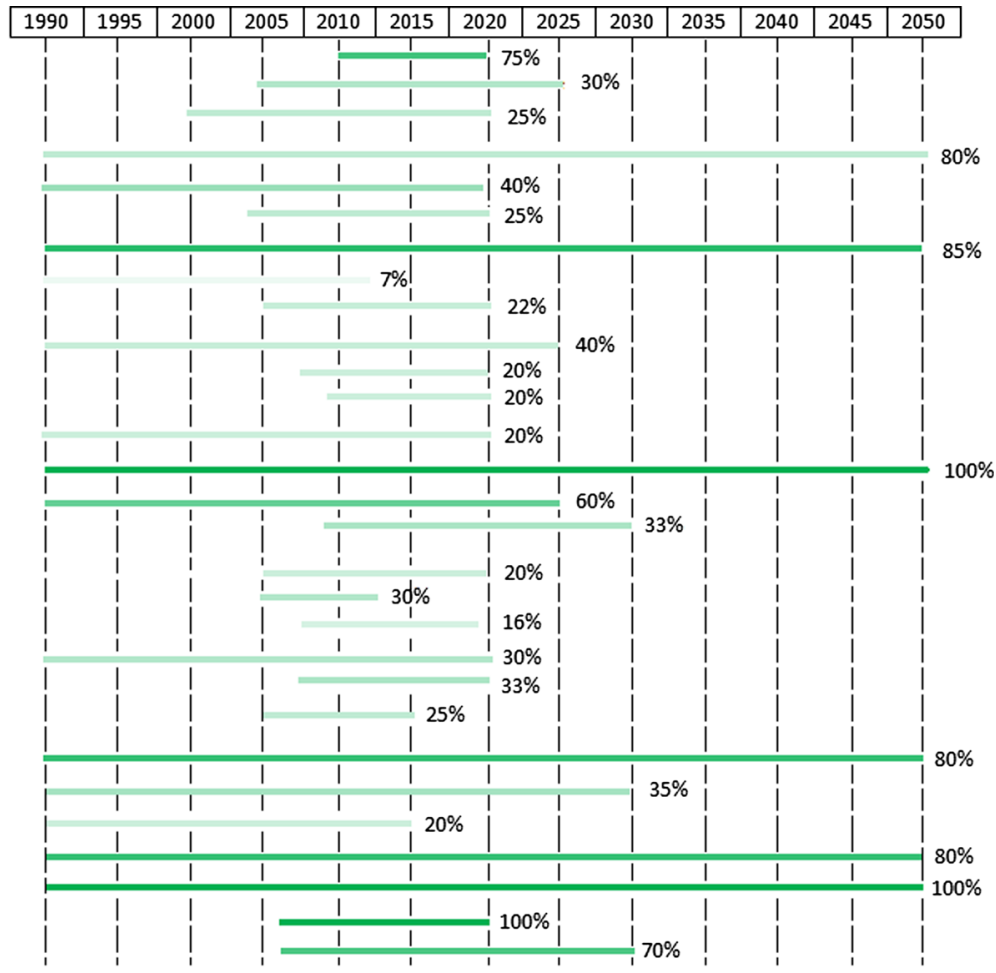

Emission reduction level shaded according to \% $\begin{array}{llllllllll}10 & 20 & 30 & 40 & 50 & 60 & 70 & 80 & 90 & 100\end{array}$

Fig. 3 C40 member commitments (excluding members without targets)

networks (the NEG/ECP, and supposedly the CoM as it is the base year of the EU's target) and a majority of the Parties to the UNFCCC (see e.g., UNFCCC 2014a, b, c), we used it as a preferred timescale for our analysis. The WCI provides supporting information referencing its target against 1990 levels, which de facto translates into a $2 \%$ increase in emissions (WCI 2007). Furthermore, the Climate Alliance's target represents a $30.5 \%$ reduction in emissions by 2020 compared with 1990 levels. ${ }^{5}$ Figure 4 represents the four TMNs' targets on a 1990-2020 timescale. By overcoming the differences in terms of metrics and timescales, significant differences between the networks become apparent. This heterogeneity again counters sweeping statements about TMNs' mitigation ambition.

Having discussed the type and framing of commitments the TMNs take, we proceed with a comparison of their ambition levels to targets agreed under the UNFCCC. To this end, we analyze the compilations of targets submitted to the Secretariat by Annex-I Parties as well as the mitigation pledges put forward by non-Annex-I Parties in the context of Nationally Appropriate Mitigation Actions (see UNFCCC 2014b, c). We only consider

\footnotetext{
5 Here we assumed that members began cutting emissions in 2006 that EU-27 emissions were $2.5 \%$ lower in 2006 than in 1990 (Olivier et al. 2013), and that the mitigation path is indexed on 2006 as base year. Changing just the last factor would move the target from $-30.5 \%$ to $-27.3 \%$ compared to 1990 , thereby decreasing the network's mitigation ambition.
} 


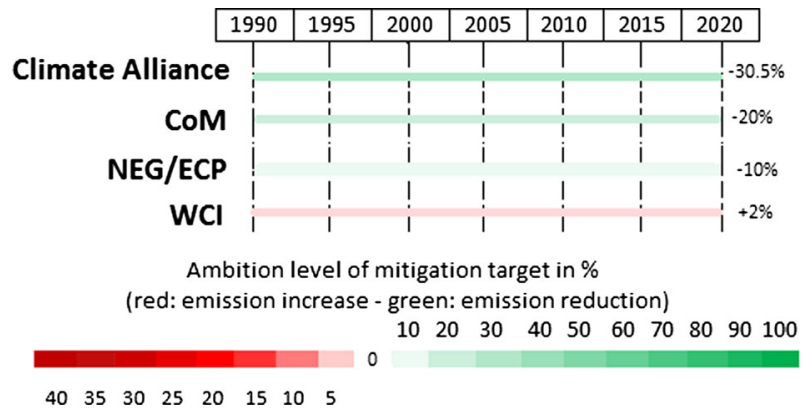

Fig. 4 Emission reduction targets of TMNs

unconditional targets set in absolute terms, which excludes some targets that are conditional upon other Parties taking similar action as well as the many targets framed against business as usual projections. Only two of the remaining Parties did not use 1990 as base year: Australia and Japan, respectively, used 2000 and 2005. Therefore, we converted these to a 1990-2020 timescale based on the emission progression between the different base years. According to its National Greenhouse Emissions Information System (AGEIS), Australian emissions increased by $18 \%$ between 1990 and 2000 (AGEIS 2015). This means that the country's target of a $5 \%$ reduction compared to 2000 corresponds to a $12 \%$ increase in emission compared to 1990. Based on the data of the Japanese Greenhouse Gas Inventory Office (GIO 2015), we found that the country's target corresponds to a $5.8 \%$ increase in emissions by 2020 compared with 1990 levels. Averaging the reduction levels of the considered targets (ranging from a $12 \%$ increase to a $30 \%$ decrease), we found that Parties to the UNFCCC on average commit to an $11.3 \%$ reduction in emissions by 2020 compared to 1990. As illustrated in Fig. 4, of the thirteen TMNs we studied, only the Climate Alliance and the CoM committed to 'above-average targets.'

While, as illustrated by Fig. 3, individual subnational governments at times are more ambitious than Parties under the UNFCCC, the same does not apply for TMNs in general. Particularly bearing in mind that most network members are based in Annex-I countries of the Global North (see Sect. 3), we therefore argue that TMNs currently do not live up to expectations and fall short of their potential with regard to mitigation ambition.

\section{Monitoring, reporting and verification}

Addressing Barber's (2013) premise that TMNs are pragmatic and focus on solutions rather than on politic sovereignty, we now examine how transparent and accountable their mitigation actions are. Bearing in mind that 'what gets measured gets managed,' we compare the reporting requirements of Parties to the UNFCCC with those of the TMNs. Although its monitoring, reporting and verification (MRV) system are continuously being negotiated (see UNFCCC 2015b), the UNFCCC's reporting requirements grew more robust over the years. As outlined on the Convention's Web site (see UNFCCC 2015a), major cornerstones of the UNFCCC's MRV system are the national communications that have to be submitted every 4 years as well as the biennial reports (for developed countries) and biennial update reports (for developing countries). Special consideration is given to least developed countries (LDCs) and Small Island Developing States (SIDS): Owing to 
their vulnerable circumstances, reporting requirements are more lax. Beyond prompting Parties to monitor their emissions, the UNFCCC makes this information publically available and reviews it (UNFCCC 2015a), which allows various stakeholders and the broader public to track progress and evaluate the effectiveness of international climate action under the UNFCCC.

Analyzing reporting documentation available on the TMNs' Web sites, we find that that the MRV provisions are of uneven stringency and comprehensiveness. Based on their reporting requirements, we grouped the networks in three types, which interestingly enough match the categorization previously made with regard to mitigation ambition. A first group of TNMs, comprising nine of the thirteen in our sample, do not have reporting requirements. Some of them do not have any documentation of their activities (e.g., WMCCC 2014), some issue yearly reports that are more forward looking statements of intent than assessments of past activities (e.g., EUROCITIES 2014), and others again highlight mitigation actions by selected individual members (e.g., Energy Cities). We consider the $\mathrm{C} 40$ as being at the periphery of this category: Although we did not find evidence of mandatory reporting procedures, the network is highly involved in initiatives promoting the comprehensive monitoring and reporting of subnational mitigation action (e.g., through the carbon $n$ climate registry).

The NEG/ECP and the WCI constitute a second type of network. Although we did not find publicly available reports, the networks appear to have some procedures in place. For the NEG/ECP, the evidence is anecdotal and takes the form of a reference to 'the 1990-2011 regional Greenhouse Gas inventory' in its resolution 37-4 (NEG/ECP 2013). For the WCI, we found more robust evidence: It created a Reporting Committee that published a guiding document on 'Essential Requirements for Mandatory Reporting' (WCI 2009) and, although they are not publicly available, it requires its members' reports to undergo third-party validation (WCI 2013).

The third type, encompassing the Climate Alliance and the CoM, has procedures for monitoring and public reporting (CoM 2013, 2014c; Klimabündnis 2001, 2011a). Their members commit to prepare and submit reports with the 'aim to check the compliance of the interim results with the foreseen objectives in terms of measures implemented and $\mathrm{CO}_{2}$ emission reductions' (CoM 2014c). Both networks however seem to acknowledge that their members' performance in this regard is not satisfactory. The Climate Alliance launched an initiative aimed at developing the members' monitoring capacities (Klimabündnis 2011b). The CoM appears to have tightened the application of its termination/suspension procedure in case of non-compliance with reporting commitments (CoM 2014e).

Here again, our analysis shows that contrary to the UNFCCC, the type and stringency of monitoring requirements are not dependent on specific criteria, such as the members' economic development. At the present stage, TMNs do not live up to the comparison with the UNFCCC concerning monitoring and reporting, which is an essential prerequisite for transparent and traceable mitigation action.

\section{Conclusions}

In this article, we analyzed the overall institutional architecture of transnational municipal networks active in the field of climate change governance with a view toward their overall performance in terms of emission reductions (we have deliberately excluded other 
outcomes of TMN activities, such as learning and adaptive behavior). In particular, we have scrutinized to what extent TMNs are a viable alternative for or effective addition to deadlocked international climate policy by analyzing four features: first, the regional spread of urban climate governance; second, the question of duplication and overlap of commitments; third, the ambition level of mitigation targets; and fourth, existing monitoring mechanisms to report and verify commitments.

In relation to the first question, geographical spread, we find a high concentration of cities and regions in the Global North, in particular Europe and the USA. In Latin America, Oceania and Asia, a scattered pattern of city participation emerges, mainly comprising capitals and large cities. In Africa on the other hand, except South Africa, most countries have very few to no cities engaging in TMNs. Overall, the geographical distribution of cities and regions active in TMNs across the globe highlights a crucial gap in the existing structure urban climate governance: While historic emitters are well-represented, fastgrowing regions are underrepresented.

In relation to our second question, duplication and overlap, we find that the central actors identified by the network analysis reflect the concentration of TMNs in Europe and North America. Among the so-called super-connectors, not a single city or region is situated within a developing country. In sum, TMNs are not an alternative form of climate governance, but rather replicate existing policy networks mainly among the USA and Europe.

Related to our third question, our analysis showed that TMNs differ notably when it comes to mitigation ambition. Most networks do not set quantified emission reduction targets to begin with and the ambition level of the four networks that do is highly variable. Only two out of thirteen TMNs set more ambitious targets than the average of targets set by Parties to the UNFCCC. This highlights that contrary to the prevalent narrative, the aggregate system of transnational municipal climate governance cannot be considered more ambitious than the multilateral level when it comes to climate change mitigation.

Finally, related to the question of monitoring and reporting, we find that nine out of thirteen TMNs do not have any reporting mechanisms in place while only two networks have explicit provisions for monitoring and reporting (two networks having some implicit frameworks in place). We consequently conclude that there is ample room for improvement with regard to measuring the networks' mitigation action.

Transnational municipal networks are a heterogeneous phenomenon that, considering its prominence in the international climate governance debate, is certainly worth further research. Building on our analysis, the next step is to move from theory to practice and examine the level of implementation of the TMNs' commitments. Evidence from the CoM for example suggests that there is a significant gap between the stated target of the network and the reality at member level: In practice $20.8 \%$ of the commitments are based on per capita emissions instead of absolute terms (CoM 2014a), and only $1.9 \%$ of the targets are set against a 1990 baseline compared to $29.7 \%$ using 2005 and $17.5 \%$ using 2013 . Attention should also be devoted to additionality and double-counting from a vertical perspective (as opposed to the horizontal perspective we addressed here), especially with regard to prominent claims that TMNs could contribute to bridging the emission gap (e.g., Blok et al. 2012). This expectation stands in contradiction with the fact that emission reductions achieved by subnational governments are accounted for (and claimed) by their respective Parties. Considering our analysis showed that most TMNs focus on soft mitigation measures (such as fostering knowledge exchange or capacity building) rather than quantified mitigation targets, another line of inquiry worth pursuing relates to the emission reductions achieved by such measures. In sum, subnational governments might be 
markedly shaping the climate leadership narrative, but transnational municipal networks are not (yet) the representative, ambitious and transparent player they are thought to be.

Open Access This article is distributed under the terms of the Creative Commons Attribution 4.0 International License (http://creativecommons.org/licenses/by/4.0/), which permits unrestricted use, distribution, and reproduction in any medium, provided you give appropriate credit to the original author(s) and the source, provide a link to the Creative Commons license, and indicate if changes were made.

\section{References}

Acuto, M. (2013). The new climate leaders. Review of International Studies, 39(4), 835-857.

AGEIS. (2015). National greenhouse gas inventory-Kyoto protocol accounting framework. Available online at http://ageis.climatechange.gov.au/. Retrieved on 12/05/2015.

Barber, B. R. (2013). If mayors ruled the world: dysfunctional nations, rising cities. New Haven: Yale University Press.

Betsill, M. M., \& Bulkeley, H. (2004). Transnational networks and global environmental governance: The cities for Climate Protection program. International Studies Quarterly, 48(2), 471-493.

Betsill, M. M., \& Bulkeley, H. (2006). Cities and the multilevel governance of global climate change. Global Governance, 12(2), 141-159.

Blok, K., Hoehne, N., van der Leun, K., \& Harrison, N. (2012). Bridging the greenhouse-gas emissions gap. Nature Climate Change, 2(7), 471-474.

Bodansky, \& Diringer (2014). alternative Models for the 2015 climate change agreement. FNI Climate Policy Perspectives 13. October 2014.

Bouteligier, S. (2013). Inequality in new global governance arrangements: The North-South divide in transnational municipal networks. Innovation: The European Journal of Social Science Research, 26(3), 251-267.

Bulkeley, H. (2005). Reconfiguring environmental governance: Towards a politics of scales and networks. Political Geography, 24(2005), 875-902.

Bulkeley, H. (2010a). Cities and the governing of climate change. Annual Review of Environment and Resources, 35(2010), 229-253.

Bulkeley, H. (2010b). Cities and the governing of climate change. Annual Review of Environment and Resources, 35, 229-253.

Bulkeley, H., Andonova, L., Bäckstrand, K., Betsill, M., Compagnon, D., Duffy, R., et al. (2012a). Governing climate change transnationally: Assessing the evidence from a database of sixty initiatives. Environment and Planning C: Government and Policy, 30, 591.

Bulkeley, H., \& Betsill, M. M. (2013). Revisiting the urban politics of climate change. Environmental Politics, 22(1), 136-154.

Bulkeley, H., \& Castan Broto, V. (2012). Government by experiment? Global cities and the governing of climate change. Transactions of the Institute of British Geographers, 38(3), 361-375.

Bulkeley, H., Castan Broto, V., \& Edwards, G. (2012b). Bringing climate change to the city: Towards low carbon urbanism? Local Environment, 17(5), 545-551.

Bulkeley, H., \& Schroeder, H. (2011). Beyond state/non-state divides: Global cities and the governing of climate change. European Journal of International Relations, 18(4), 743-766.

C40. (2014a). The power of C40 cities. Available online at http://www.c40.org/cities. Retrieved on 06/06/ 2014.

C40. (2014b). Global standards. Measurement and Planning Initiative. Available online at http://www.c40. org/networks/global_standards. Retrieved on 11/11/2014.

Castan Broto, V., \& Bulkeley, H. (2013). A survey of urban climate change experiments in 100 cities. Global Environmental Change, 23(2013), 92-102.

Collier, U., \& Löfstedt, R. E. (1997). Think globally, act locally? Local climate change and energy policies in Sweden and the UK. Global Environmental Change, 7(1), 25-40.

CoM. (2013). Monitoring report system to be available as of 2013. Available online at http://www. eumayors.eu/news_en.html?id_news=349. Retrieved on 04/11/2014.

CoM. (2014a). The Covenant in figures. Available online at http://www.covenantofmayors.eu/about/ covenant-in-figures_en.html. Retrieved on 17/06/2014.

CoM. (2014b). The Covenant of mayors. Available online at http://www.covenantofmayors.eu/about/ covenant-of-mayors_en.html. Retrieved on 17/06/2014. 
CoM. (2014c). Implementation reports. Available online at http://www.covenantofmayors.eu/about/ covenant-step-by-step-implementation\%20reports_en.html. Retrieved on 27/10/2014.

CoM. (2014e). FAQ. Available online at http://www.covenantofmayors.eu/support/faq_en.html?id_faq=77. Retrieved online on 28/10/2014.

Comodi, G., Cioccolanti, L., Polonara, F., \& Brandoni, C. (2012). Local authorities in the context of energy and climate policy. Energy Policy, 51, 737-748.

Corfee-Morlot, J., Kamal-Chaoui, L., Donovan, M. G., Cochran, I., Robert, A., \& Teasdale, P.-J. (2009). Cities, climate change and multilevel governance. OECD Environmental Working Papers No. 14, 2009, OECD Publishing.

De Sherbinin, A., Schiller, A., \& Pulsipher, A. (2007). The vulnerability of global cities to climate hazards. Environment and Urbanization, 19(1), 39-64.

Energy Cities. (2015). Breaking news: \#COP21 cancelled as cities have put the world back on track. Available online at http://www.energy-cities.eu/Breaking-news-COP21-cancelled-as. Retrieved on $09 / 05 / 2015$.

EUROCITIES. (2014). Climate. Available online at http://www.eurocities.eu/eurocities/priorities/climate. Retrieved on 17/06/2014.

Fünfgeld, H. (2015). Facilitating local climate change adaptation through transnational municipal networks. Current Opinion in Environmental Sustainability, 12(2015), 67-73.

Giest, S., \& Howlett, M. (2013). Comparative climate change governance: Lessons from European transnational municipal networks management efforts. Environmental Policy and Governance, 239, $341-353$.

GIO. (2015). The GHGs Emissions Data of Japan (1990-2013). Available online at http://www-gio.nies.go. jp/aboutghg/nir/nir-e.html. Retrieved on 12/05/2015.

Granberg, M., \& Elander, I. (2007). Local governance and climate change: Reflections on the Swedish experience. Local Environment: The International Journal of Justice and Sustainability, 12(5), 537-548.

Gustavsson, E., Elander, I., \& Lundmark, M. (2009). Multilevel governance, networking cities, and the geography of climate-change mitigation: Two Swedish examples. Environment and Planning $C$ : Government and Policy, 27(1), 59-74.

Hoornweg, D., Sugar, L., \& Gomez, C. L. T. (2011). Cities and greenhouse gas emissions: moving forward. Environment and Urbanization, 23(1), 207-227.

JRC. (2014). Global $\mathrm{CO}_{2}$ emissions increase to new all-time record, but growth is slowing down. JRC Science Hub. https://ec.europa.eu/jrc/en/news/global-co2-emissions-increase-new-all-time-recordgrowth-slowing-down.

Juhola, S., \& Westerhoff, L. (2011). Challenges of adaptation to climate change across multiple scales: A case study of network governance in two European countries. Environmental Science \& Policy, 14(2011), 239-247.

Kamal-Chaoui, L., \& Robert, A. (Eds.). (2009). Competitive cities and climate change. OECD Regional Development Working Papers No. 2, 2009, OECD Publishing.

Kern, K., \& Bulkeley, H. (2009). Cities, Europeanization and multi-level governance: Governing climate change through transnational municipal networks. JCMS: Journal of Common Market Studies, 47(2), 309-332.

Klimabündnis. (2001). Empfehlungen des Arbeitskreises "CO2-Reduktionsstrategien im Klima-Bündnis" zur Erstellung des kommunalen Klimaschutzberichtes. Available online at http://www.klimabuendnis. org/412.html?\&L=1. Retrieved on 26/10/2014.

Klimabündnis. (2011a). CO2 monitoring within Climate Alliance. Available online at http://www. klimabuendnis.org/fileadmin/inhalte/dokumente/2012/co2-monitoring-methogology_en.pdf. Retrieved on $26 / 10 / 2014$.

Klimabündnis. (2011b). CLIMATE COMPASS: A roadmap for local climate protection. Available online at http://www.klimabuendnis.org/fileadmin/inhalte/dokumente/2011/ClimateCompass_leaflet-en.pdf. Retrieved on 09/11/2014.

Klimabündnis. (2014). Our objectives. Available online at http://www.klimabuendnis.org/our-objectives0.0. html. Retrieved on 27/05/2014.

Kousky, C., \& Schneider, S. H. (2003). Global climate policy: Will cities lead the way? Climate Policy, 3(4), 359-372.

Krause, R. M. (2012). An assessment of the impact that participation in local climate networks has on cities's implementation of climate, energy, and transportation policies. Review of Policy Research, 29(5), 585-604.

Lee, T. (2013). Global cities and transnational climate change networks. Global Environmental Politics, 13(1), 108-127. 
Lee, T., \& Koski, C. (2014). Mitigating global warming in global cities: Comparing participation and climate change policies of C40 cities. Journal of Comparative Policy Analysis, 16(5), 475-492.

Lee, T., \& van de Meene, S. (2012). Who teaches and who learns? Policy learning through the C40 cities climate network. Policy Sciences, 45(2012), 199-220.

NA2050. (2014). About. Available online at http://na2050.org/about/. Retrieved on 17/06/2014.

NEG/ECP. (2001). New England Governors/Eastern Canadian Premiers Climate Change Action Plan 2001. Available online at http://negc.org/uploads/file/Reports/ClimateChangeAP\%5B1\%5D.pdf. Retrieved on $28 / 05 / 2014$.

NEG/ECP. (2013). 37th Annual Conference of New England Governors \& Eastern Canadian Premiers. Resolution 37-4 concerning climate change. Available online at http:/www.cap-cpma.ca/images/ ECP\%20Documents/NEG-ECP\%20Resolution\%2037-4\%20Climate\%20Change\%20EN.pdf. Retrieved on 31/10/2014.

Olivier, J. G. J., Janssens-Maenhout, G., Muntean, M., \& Peters J. A. H. W. (2013): Trends in global $\mathrm{CO}_{2}$ emissions: 2013 Report. ISBN: 978-94-91506-51-2, PBL publication number: 1148, JRC Technical Note number: JRC83593.

Olivier, J. G. J., Janssens-Maenhout, G., Muntean, M., \& Peters, J. (2014). Trends in global $\mathrm{CO}_{2}$ emissions: 2014 Report. 1490. The Hague: PBL Netherlands Environmental Assessment Agency.

Ostrom, E. (2009). A polycentric approach for coping with climate change.

Pauw, P., Bauer, S., Richerzhagen, C., Brandi, C., \& Schmole, H. (2014). Different perspectives on differentiated responsibilities. Discussion paper. Deutsches Institut für Entwicklungspolitik. Available online at https://www.die-gdi.de/uploads/media/DP_6.2014.pdf. Retrieved on 25/07/2015.

R20. (2014). Become a member. Available online at http://www.regions20.org/join-us/become-a-member. Retrieved on 17.06.2014.

Rosenzweig, C., Solecki, W., Hammer, S., \& Mehrotra, S. (2010). Cities lead the way in climate-change action. Nature, 467, 909-911.

Schreurs, M. (2008). From the bottom up. Local and subnational climate change politics. The Journal of Environment and Development, 17(4), 343-355.

Schroeder, H., \& Lovell, H. (2009). The role of side events in the UNFCCC Climate Negotiations. In: Amsterdam Conference on the Human Dimensions of Global Environmental Change, Amsterdam.

The Climate Group. (2014). The Climate Group Announces Strategic Partnership with the New China Regional Low Carbon Alliance. July 7. http://www.theclimategroup.org/what-we-do/news-and-blogs/ the-climate-group-announces-strategic-partnership-with-the-new-china-regional-low-carbon-alliance/.

Toly, N. J. (2008). Transnational municipal networks in climate politics: From global governance to global politics. Globalizations, 5(3), 341-356.

UNCED. (1992). United Nations Conference on Environment \& Development. Rio de Janeiro, Brazil, 3 to 14 June 1992. AGENDA 21. Available online at http://sustainabledevelopment.un.org/content/ documents/Agenda21.pdf. Retrieved on 21/06/2014.

UNEP. (2015). Climate Commitments of Subnational Actors and Business: A Quantitative Assessment of Their Emission Reduction Impact. Nairobi, Kenya: United Nations Environment Programme (UNEP).

UNFCCC. (2010). Non-governmental organization constituencies. Available online at https://unfccc.int/ files/parties_and_observers/ngo/application/pdf/ngo_constituencies_2010_english.pdf. Retrieved on 26/10/2014.

UNFCCC. (2014a). Climate Change Information Sheet 17. The international response to climate change. Available online at http://unfecc.int/essential_background/background_publications_htmlpdf/climate_ change_information_kit/items/300.php UNFCCC. Retrieved on 03/11/2014.

UNFCCC. (2014b). Appendix II-Nationally appropriate mitigation actions of developing country Parties. Available online at http://unfccc.int/meetings/cop_15/copenhagen_accord/items/5265.php. Retrieved on $12 / 06 / 2014$.

UNFCCC. (2014c). Compilation of economy-wide emission reduction targets to be implemented by Parties included in Annex I to the Convention. Note by the secretariat. Available online at http://unfccc.int/ resource/docs/2014/sbsta/eng/inf06.pdf. Retrieved on 12/06/2014.

UNFCCC. (2015a). National Reports. Available online at http://unfccc.int/national_reports/items/1408.php. Retrieved on 15/03/2015.

UNFCCC. (2015b). Ad Hoc Working Group on the Durban Platform for Enhanced Action, Negotiating text. FCCC/ADP/2015/1. Available online at http://unfecc.int/resource/docs/2015/adp2/eng/01.pdf. Retrieved on 13.05.2015.

UN-Habitat. (2011). Cities and climate change: Global report on human settlements 2011. London: Earthscan.

WCI. (2007). Statement of Regional Goal. Available online at http:/www.westernclimateinitiative.org/ document-archives/general/Emission-Reduction-Goal-Aug-2007. Retrieved on 31/10/2014. 
WCI. (2009). Final Essential Requirements of Mandatory Reporting. Available online at http://www. westernclimateinitiative.org/component/remository/Reporting-Committee-Documents/Final-EssentialRequirements-for-Mandatory-Reporting/. Retrieved on 16/03/2015.

WCI. (2013). Frequently Asked Questions. Available online at http://www.westernclimateinitiative.org/thewci-cap-and-trade-program/faq\#question10. Retrieved on 04/11/2014.

Widerberg, O., \& Pattberg, P. (2015). International Cooperative Initiatives in Global Climate Governance: Raising the Ambition Level or Delegitimizing the UNFCCC? Global Policy, 6(1), 45-56.

WMCCC. (2014). Mission and Method. Available online at http://www.worldmayorscouncil.org/about/ mission-and-method.html. Retrieved on 17/06/2014.

WRI. (2014). CAIT. 2.0., 2014. Climate Analysis Indicators Tool: WRI's Climate Data Explorer. Washington, DC: World Resources Institute. 